\title{
Unipotent or Multipotent Mammary Stem/Progenitor Cells in Mouse Mammary Gland Development
}

\author{
Gilbert H Smith* \\ Mammary Stem Cell Biology Section, CCR, NCI, USA
}

Submission: June 07, 2018; Published: July18, 2018

*Corresponding author: Gilbert H Smith, PhD, Mammary Stem Cell Biology Section, BRL, CCR, NCI, Bethesda, MD 20892, USA, Tel: 240-7607698; Email: smithg@mail.nih.gov

\begin{abstract}
An ongoing debate in the developmental literature is whether the mouse mammary gland arises from a unipotent or multipotent progenitor population.We believe that a review of the evidence clearly supports the argument that multipotent stem/progenitor cells exist among the epithelium of mouse mammary glands in adult animals. Here we present our published data, which does not align well with the current ideas of the mammary epithelial stem cell hierarchy. Some questions remain that must be taken into account. However it is clear from our published observations that stemmness is more properly considered as a function rather than a unique inherent property of specific cells within any given tissue.
\end{abstract}

Keywords: Mus musculus; Stem cell; Mammary; Transplantation; Reprogramming

\section{Introduction}

The purpose in this discussion is to present the argument that multipotent stem/progenitor cells exist among the epithelium of mouse mammary glands in adult animals. Mammary biologists have been informed in recent years that there is no role for multipotent mammary stem cells in mouse mammary development[1,2]. However, results in the literature argue against this interpretation. It should be noted that experiments conducted with adult allophenic mice (produced by the fusion of embryonic blastomeres of mice having distinctly different histocompatibility alleles) demonstrate that mammary glands contain cells from each donor and therefore must arise from at least two antecedent cells [3]. Thus, mammary fragments from these mice produce outgrowths in the cleared mammary fat pads in each of the donor $\mathrm{H} 2$ incompatible strains.

What is the Significance of the Regenerative Activity Resident in Mammary Epithelium?

Any portion of the mammary epithelium at any age or regardless of reproductive history is capable upon transplantation of regenerating an entire mammary epithelial outgrowth upon transplantation into an epithelium-divested mammary fat pad. In addition, this can be repeated serially without consideration of age or reproductive history [4,5]. Two experiments come to mind: First, if lineage-limited unipotent progenitors are paramount to mammary epithelial regeneration then transplantation of old multiparous mouse mammary gland as fragments or cells (by titration) should contain previously marked lineage-limited mammary epithelial cells. For example, ER-alpha positive and negative progenitor cells may be marked by Sox-9-CreER and Prominin-1-CreER respectively on postnatal day 28[6]. If after several pregnancies these cells give rise to ER-positive or ER-negative progeny respectively when tissue fragments or limited dilution dispersed cells then this would provide evidence that lineage-limited progenitors are responsible for the long-lived regenerative capacity of transplanted mammary tissue. However, if only unlabeled luminal cells are produced in these outgrowths then this would argue for the de-novo origination of these lineage-limited progenitors from a multipotent antecedent. A second experiment would be the separation of luminal and basal cell populations from a retrovirally-marked mammary outgrowth $[7,8]$ and demonstration that these distinct epithelial subsets are derived from a single antecedent bythe demonstration of identical host-viral restriction fragments in each subset.

There is a striking difference in transplantation results when one compares the outgrowths produced from inoculation of dispersed cells with those obtained from implanted mammary tissue fragments containing epithelium. Barring technical difficulties, one can expect and nearly always observes a complete functional mammary epithelial outgrowth that fills the entire implanted fat pad, 10-12 weeks after transplanting mammary tissue fragments. Fragments typically contain $\sim 7000$ epithelial cells as measured by cellular dispersal of the typical implant fragments $(\sim 1.0 \mathrm{~mm} 3)$. 
On the other hand, to obtain similar results with freshly dispersed mammary epithelial cells, one needs to inoculate approximately 10-12 times as many cells in saline. Thus, most studies involving isolated cells at 7000 or less fail to produce full filling of the fat pad most of the time when transplanted without added stroma and growth factors. Our interpretation of this difference is that the mammary stem cell niche, an anatomically defined site where stem cells are maintained uninfluenced by signals to differentiate, is intact in the fragments throughout the lifetime of the mouse. Dispersal of the epithelial cells into single cell preparations leads to disruption of these anatomically-defined sites.Therefore, successful complete outgrowth requires the re-aggregation of the stem/progenitor with the appropriate components of its niche (including the stromal components) when dispersed epithelial cells are inoculated into the cleared mammary fat pads. This was shown dramatically by Welm et al. [9], who describe implants of lentivirus-transduced mammary cells both as tissue fragments and dispersed reporter-positive cells. A heterogeneous epithelial outgrowth comprised of both luminal and basal cells with and without hormone-receptor expression, was produced in all instances. This supports the conclusion that a multipotent epithelial mammary stem cell exists within the mammary epithelial population.In other studies[10,11]it was shown that ductal development and secretory lobular development were independent of one another[7,12]. Thus, when dispersed cells are transplanted (10-2000), one obtains outgrowths that are partial (i.e. not representative of complete mammary epithelial development following pregnancy) because independent lineagelimited progenitor cells exercised their prerogative to create an incomplete mammary epithelial outgrowth.

\section{Can this Activity be Assigned to a Single Antecedent?}

Our research [7] demonstrated by random fragment serial transplantation and retroviral tagging that an entire functional mammary epithelial outgrowth could be generated from the progeny of a single predecessor. Our conclusion, at that time, was that a single multipotent mammary epithelial stem cell was responsible for all the epithelium and was self-renewing. Recent reports [1,2] have indicated that unipotent progenitor cells can contribute extensively to mammary epithelial growth. These studies prompted us to re-examine our original conclusion and modify it to one which now recognizes that lineage-limited progenitors, present within the fragment, may contribute extensively to the epithelial progeny of clonal mammary outgrowths. The progeny of these lineage-limited cells must be the direct progeny of a single multipotent mammary epithelial stem cell because retroviral marking indicates that all outgrowths maintain the same MMTV-host DNA restriction fragments. It has been conclusively shown that a complete functional epithelial outgrowth is comprised of the offspring of a single ancestor[6,7-12]. This argues that, a multipotent mammary epithelial stem cell exists within the mammary gland in situ. Maintenance of the different types of luminal and basal mammary epithelium on a day to day basis may be best characterized by replacement from lineage-limited forbears. Recently the hormone-receptor-positive and hormone-receptor-negative luminal epithelium has been reported to arise from distinct lineage-limited progenitors that express distinct genetic markers [6].

\section{Experimental Evidence that Remains Unexplained by the Current Stem/Progenitor Cell Models}

In 1996, Smith [13] showed that limiting dilutions (2000) of dispersed WAP-LacZ-positive mammary epithelial cells produced lobule-limited and duct-limited outgrowths in syngeneic mammary fat pads when inoculated with 1 X 106 unmarked mammary-derived fibroblasts. Fibroblasts alone did not produce outgrowths. This was the 1st demonstration of lineage limited mammary epithelial progenitors. These structures contained both hormone-receptorpositive and negative luminal cells and myoepithelial (basal)cells [6].

Smith \& Boulanger [8] demonstrated that lobular and ductal development were lost independently from one another during serial transplantation of fragments from a clonally-derived mammary outgrowth in vivo, this observation supports the presence of lineage limited epithelial progenitors in intact mammary tissue.

A series of publications [14-20] indicate that the mammary microenvironment can re-direct adult stem cells and cancer cells to mammary epithelial cell fates and that these re-directed cells contribute mammary progeny in subsequent fragment transplant outgrowths in vivo. These experiments support the notion that nonmammary cells are susceptible to the developmental signals present in the mammary microenvironment and are capable subsequently of self-renewal. In addition, cell-free preparation from adult rat or mouse mammary gland direct testicular and embryonic stem cells to form complete mammary epithelial outgrowths in vivo[20].

The immediate conclusion that is suggested by these experiments is that the microenvironment exerts a powerful influence upon cellular fate(s). This is particularly striking when one considers the effect of normal functioning cells in a normal stroma has upon cancer-forming cells. Further study of this effect and how it is manifested promises new and less debilitating treatments for cancer in situ.

\section{References}

1. Wuidart A, Ousset M, Rulands S, Simons BD, Van Keymeulen A, et al. (2016) Quantitative lineage tracing strategies to resolve multipotency in tissue-specific stem cells. Genes Dev 30(11): 1261-1277.

2. Van Keymeulen A, Rocha AS, Ousset M, Beck B, Bouvencourt G, et al. (2011) Distinct stem cells contribute to mammary gland development and maintenance. Nature 479(7372): 189-193.

3. Mintz B, Slemmer G (1969) Gene control of neoplasia. I. genotypic mosaicism in normal and preneoplastic mammary glands of allophenic mice. J Natl Cancer Inst 43(1): 87-109.

4. Young LJ, Medina D, DeOme KB, Daniel CW (1971) The influence of host and tissue age on life span and growth rate of serially transplanted mouse mammary gland. Exp Gerontol 6(1): 49-56.

5. Raafat A, Strizzi L, Lashin K, Ginsburg E, McCurdy D, et al. (2012) Effects of age and parity on mammary gland lesions and progenitor cells in the FVB/N-RC mice. Plos One 7(8): e43624. 
6. Wang C, Christin JR, Oktay MH, Guo W (2017) Lineage-biased stem cells maintain estrogen-receptor-positive and -negative mouse mammary luminal lineages. Cell Rep 18(12): 2825-2835.

7. Kordon EC, Smith GH (1998) An entire functional mammary gland may comprise the progeny from a single cell. Development 125(10): 19211930.

8. Smith GH, Boulanger CA (2002) Mammary stem cell repertoire: new insights in aging epithelial populations. Mech Ageing Dev 123(11): 1505-1519.

9. Welm BE, Dijkgraaf GJ, Bledau AS, Welm AL, Werb Z (2008) Lentiviral transduction of mammary stem cells for analysis of gene function during development and cancer. Cell Stem Cell 2(1): 90-102.

10. Danielson KG, Oborn CJ, Durban EM, Butel JS, Medina D (1984) Epithelial mouse mammary cell line exhibiting normal morphogenesis in vivo and functional differentiation in vitro. Proc Natl Acad Sci USA 81(12): 3756-3760.

11. Kordon EC, McKnight RA, Jhappan C, Hennighausen L, Merlino G, et al. (1995) Ectopic TGF beta 1 expression in the secretory mammary epithelium induces early senescence of the epithelial stem cell population. Dev Biol 168(1): 47-61.

12. Daniel CW, Young LJ, Medina D, DeOme KB (1971) Influence of mammogenic hormones on serially transplanted mouse mammary gland. Exp Gerontol 6(1): 95-101.

13. Smith GH (1996) Experimental mammary epithelial morphogenesis in an in vivo model: evidence for distinct cellular progenitors of the ductal and lobular phenotype. Breast Cancer Res Treat 39(1): 21-31.
14. Boulanger CA, Mack DL, Booth BW, Smith GH (2007) Interaction with the mammary microenvironment redirects spermatogenic cell fate in vivo. Proc Natl Acad Sci USA 104(10): 3871-3876.

15. Booth BW, Mack DL, Androutsellis-Theotokis A, McKay RD, Boulanger CA, et al. (2008) The mammary microenvironment alters the differentiation repertoire of neural stem cells. Proc Natl Acad Sci USA 105(39): 14891-14896.

16. Boulanger CA, Bruno RD, Rosu-Myles M, Smith GH (2012) The mouse mammary microenvironment redirects mesoderm-derived bone marrow cells to a mammary epithelial progenitor cell fate. Stem Cells Dev 21(6): 948-954.

17. Bussard KM, Boulanger CA, Booth BW, Bruno RD, Smith GH (2010) Reprogramming human cancer cells in the mouse mammary gland. Cancer Res 70(15): 6336-6343.

18. Bussard KM, Smith GH (2012) Human breast cancer cells are redirected to mammary epithelial cells upon interaction with the regenerating mammary gland microenvironment in-vivo. PLoS One 7(11): e49221.

19. Bruno RD, Boulanger CA, Rosenfield SM, Anderson LH, Lydon JP, et al. (2014) Paracrine-rescued lobulogenesis in chimeric outgrowths comprising progesterone-receptor-null mammary epithelium and redirected wild-type testicular cells. J Cell Sci 127(Pt 1): 27-32.

20. Bruno RD, Fleming JM, George AL, Boulanger CA, Schedin P, et al. (2017) Mammary extracellular matrix directs differentiation of testicular and embryonic stem cells to form functional mammary glands in vivo. Sci Rep 7: 40196.

\section{Your next submission with Juniper Publishers} will reach you the below assets

- Quality Editorial service

- Swift Peer Review

- Reprints availability

- E-prints Service

- Manuscript Podcast for convenient understanding

- Global attainment for your research

- Manuscript accessibility in different formats

( Pdf, E-pub, Full Text, Audio)

- Unceasing customer service

Track the below URL for one-step submission https://juniperpublishers.com/online-submission.php 